\author{
Research Article \\ (C) 2020 Xhemajli Selimaj et.al.. \\ This is an open access article licensed under the Creative Commons \\ Attribution-NonCommercial 4.o International License \\ (https://creativecommons.org/licenses/by-nc/4.o/)
}

\title{
The Impact of Public Debt in Economic Growth
}

\author{
Dr. Sc. Ariana Xhemajli Selimaj \\ Prof. Asoc. Dr. Bedri Statovci \\ Dr. Sc. Alma Shehu Lokaj \\ Msc(c). Ermira Beqiri \\ Haxhi Zeka University, Kosova
}

DOI: https://doi.org/10.36941/ajis-2020-oo72

\begin{abstract}
Different countries around the world, in addition to collecting public revenues as sources to cover public expenditures, also need other sources of funding, because frequently, most countries cannot generate sufficient budgetary revenue to afford all the budget expenditures. This is one of the reasons why public debt is created. There is always debate among economists as to what the optimal percentage of public debt should be so as not to impede the economic development of a country. To avoid impediments to economic development, then public debt management needs to be done properly so that it is earmarked for adequate projects that will contribute to economic growth and development. In this paper, we will analyse the impact of public debt on economic growth. Kosovo serves as our case study for the period 2009-2016, where remittances, exports, increase of average payments and subsidies were considered as other influencing factors. The prudent use of public debt, such as in various investments, job creation, and productivity growth, can all contribute to economic growth and financial stability. Otherwise, misuse of public debt will inadvertently affect the country's destabilization, create an inflationary situation, and will only continue to increase liabilities to lenders - essentially, it will have no positive impact on the country. Reckless use of public debt will have a direct effect on lowering the economic growth rate.
\end{abstract}

Keywords: economic growth; public debt; financial stability; GDP; well-being

\section{Definition of the problem}

Public debt is one of the non-fiscal financial instruments that is part of and has an impact on the formation of general public revenues. It is mainly borrowed from various entities, and it is used to finance budget deficits and strategic projects, among others. Public debt contains not only the obligation arising from the contract for state debt, but also other supplementary obligations, such as compensation of damages, reparations, and export of property. The importance and the effects of public debt are reflected, either directly or indirectly, in the country's economy, which can be perceived through its impact on both monetary and fiscal policy. Public debt has negative effects on the economic growth of many countries due to the fact that the repayment of interest-bearing loans represents a fiscal burden on a country's economy.

The limit of public debt depends to some extent on the ability of the economy to generate 
economic growth, as well as on the destination of debt (i.e. whether its use is for productive purposes or otherwise). Public debt would affect the creation of new jobs, higher education levels, and living conditions. Efficient use of public debt could promote economic growth and development.

\section{Purpose of the Research}

The purpose of this paper is to understand the impact of public debt on economic growth. In this way, we can obtain a complete overview of public debt, its impact on gross domestic product (GDP), and the improvement of the lives of Kosovar citizens. This analysis of public debt will also be supported by an econometric model, which is desinged to answer the research question: "Does public debt affect economic growth in Kosovo?"

\section{Hypotheses}

Based on the results of the analysis, we will draw conclusions on whether public debt has been properly developed for the Kosovo economy. Public debt analysis will also be supported by an econometric model that is built to validate the following hypotheses:

$\mathrm{H}_{1}$ : Public debt has a positive impact on economic growth;

$\mathrm{H}_{2}$ : Remittances have a positive impact on economic growth;

$\mathrm{H}_{3}$ : The increase in average pay has a positive impact on economic growth;

$\mathrm{H}_{4}$ : Exports have a positive impact on economic growth; and

$\mathrm{H}_{5}$ : Subsidies have a positive impact on economic growth.

\section{Literature Review}

According to the Kosovo Public Debt Law, debt is any financial obligation to be paid, or the obligation to pay money arising from financing contracts, treasury bills, bonds, overdrafts, or other securities transmitted in exchange for the disbursement of funds, and the obligation to pay principal, interest, deduction, provisions, commissions, or penalties of any nature (Nexhmije Berisha Vokshi, 2013). Debt remains a double-edged knife Cecchetti, Mohanty, and Zampoli (2011) emphasize that if debt is used wisely and moderately, it contributes to the improvement and enhancement of wellbeing. Borrowing has benefits in terms of growth and economic stability when used at moderate levels. However, when used improperly and excessively, it can lead to devastating results. For households and firms, excessive borrowing can lead to bankruptcy and financial ruin. For a country's economy, excessive government borrowing undermines its ability to provide the necessary services to its citizens.

According to Keynesian opinions, public debt has a positive impact on the economic activity of each country - in particular, through the public spending mechanism, arguing that the increase in public spending is a result of deficits and debt caused by expansionary fiscal policy.

As early the mid-eighteenth century, David Hume (1777) held that "the state must abolish public credit or else public credit will abolish the state". Quite the opposite is strongly stated by Carl Dietezel a hundred years later (1855), who strongly supports the entry of the state into debt, stating: "Public borrowing is a factor for strong economic progress". In this context, numerous debates have been held for a long time about the role and importance of public debt for the state, which they support, namely argue that public debt affects budget stabilization, budget deficit financing and economic development, such as and those who oppose these views, saying that public debt is a heavy burden for the economy and for future generations. Therefore, we argue that when debt, both domestic and foreign, is well used, especially for economic development, it is very profitable, and therefore states should have debt funds.

Modern economists, on the other hand, see public debt as a driver of economic growth if funds are used for productive purposes rather than for consumption of goods and services. Panizza and 
Presbitero (2013) argued in 2011 that "the effect of rising debt depends on the presence of rigidities in the economy. In a model without rigidity and lacking a flexible labour supply, public debt has a negative effect on labour supply, investment, and economic growth. In the presence of wage rigidity and unemployment, public debt has no effect on resource allocation, and it can have a positive effect on growth if used to finance productive investment"

When debts are used well for economic development, these funds are very beneficial to the country as a whole (Kryeziu, 2014). Considering that the main objective of economic growth is focused on ensuring long-term and balanced economic growth, avoiding such negative phenomena as budget deficits, inflation, and uncontrolled unemployment would be appropriate within the state to specialize special teams to analyse the effects of debt and to manage them in a qualitative way so that the debts received are used for productive purposes, for the economic development of the country, so that they are beneficial to the country, trying to more to avoid their negative effects that could burden the economy of the country, especially the population through the high tax and tax burden that would be used for their settlement (Pano, 2002).

One suggestion is that deficits are different in order to maintain continued consistency in tax rates. This behaviour implies a positive effect on the issue of the temporary growth of debt on government spending (as in times of war), a countercyclical debt response to temporary income movements, and a one-on-one effect of expected inflation on nominal growth of debt (Barro Robert J, 1979). According to Keynesian economists, at the level of full employment, an increase in public spending will reduce the level of public debt (J, Alves., 2008). According to Keynesians, an increase in debt will have an impact on the growth of national income which was linked to the increase in employment and production as a result of the increase in the level of public debt, which in turn has an impact on the growth of effective demand in the economy.

The classic conception of public debt has been opposed to public debt as a risk to society, while the contemporary conception of public debt has been opposed to being pro-debt as a means of economic progress (Kadriu, 2016). Without debt (borrowing), national economies cannot grow. However, developing and deepening the financial system is not a magic solution. Debt growth and accumulation is associated with increased risks. In terms of the relationship between external debt and economic growth, a reasonable level of borrowing is likely to boost economic growth through capital accumulation and productivity growth (Chowdhury, (2001)), and external borrowing for productive investment creates macroeconomic stability (Burnside, C. and D. Dollar, 200o). If public debt is able to meet the financing needs of the economies of the countries, its effect will be positive. The non-fulfilment of development projects will adversely affect countries' economies, and as a consequence, public debt will not be able to be used for the reasons it has been received. As different countries have different economic developments, the level of debt also varies from country to country. It is important for each country to keep the amount of public debt at a certain level, and not to exceed the set level, as the consequences can be quite severe for their economies, as in the case of Greece. Public debt includes state-level debt that is commonly used as an instrument to carry out various important projects or to emerge from a crisis and to finance the budget deficit. Despite the government's need to use public debt as an instrument to finance budget deficits or even various development projects, it is said that there is an impact of public debt on economic development.

\section{Research Methodology}

To make this paper as efficient and clear as possible, the series used are public debt, exports, remittances, average pay increases, subsidies, and the amount of GDP in millions received over the period of 2009-2016 on a monthly basis. The data used are drawn from reports from the Ministry of Finance of the Republic of Kosovo; Kosovo Agency of Statistics (KAS); Central Bank of Kosovo; World Bank reports; International Monetary Fund reports; and others. Data collection is based on secondary data we have found on the Internet, as well as reports from government agencies and other bodies of international institutions that assisted Kosovo during this period through various projects and 
programmes. Initially, description or narrative methods are used to provide theoretical information. This paper then goes on to analyse the figures and facts to give a more accurate picture of the current debt situation in terms of the country's GDP. The methodology used is based on the alternation of secondary data, such as literature from various local and international authors. This type of information assisted in the analysis carried out in this study, as well as in the methodology used to ascertain the impact of public debt on the domestic economy. The impact of some variables on GDP is also analysed in this paper. We will analyse the relation of GDP to public debt, remittances, exports, average wage increases, and subsidies.

\section{Study Limitations}

Among the major limitations of this model is the deficiency in the number of observations. It has been impossible since public debt has been taken over in its total for Kosovo, which includes both international and domestic debt, but since the start of using international debt as a tool started in 2009 in Kosovo it has therefore been impossible a larger number of observations is generated.

\subsection{The scientific-practical contribution of research}

Public debt is a problem that all countries all over the world must address. The limit of public debt depends to some extent on the ability of the economy to generate economic growth, as well as on the destination of debt (i.e. whether its use is for productive purposes). Through linear regression, we will validate the aforementioned hypotheses.

\section{Model Specification}

In this paper, multivariate econometric analysis was used to analyse the relationship between GDP as a dependent variable and as an independent variable, public debt, remittances, average wage growth, exports, and subsidies. The tests used to analyse the relationship between the variables are: correlation value, regression, significance value, and f-test.

$\mathrm{Yi}=\mathrm{a}+\mathrm{bX} 1+\mathrm{bx}_{2}+\mathrm{bx}_{3}+\mathrm{bx}_{4}+\mathrm{bx}_{5}$

$\mathrm{Yi}$ - is the dependent variable that in our case is the GDP

$\mathrm{a}-$ is the constant

$\mathrm{bX}_{1}, \mathrm{Xii}$ - are the independent variables

$\mathrm{X}_{1}=$ Public debt

$\mathrm{X}_{2}=$ remittances

$\mathrm{X}_{3}=$ Average Salary

$\mathrm{X}_{4}=$ Export

$\mathrm{X}_{5}=$ subsidies

$\mathrm{E}=$ presents the elements of error that include all other factors that have an impact on GDP, but we have not included them all in the model. It is found by the difference of 100 - the value of the determination or regression $\mathrm{R}^{2}$

\section{The Relation between the Public Debt and Economic Growth}

\subsection{Reliability analysis of variables}

Many points must be taken into account when designing a reliable measuring tool. Some of these points include the ability of the questions that make up the measurement tool, the existence of a link between them, their consistency, their comprehensibility, and sufficient numbers. The concept of reliability is needed for each measurement made, because reliability expresses consistency among the variables that are included in a test. 
Interpretations of the reliability of the meter with respect to the Alpha coefficient $(\alpha)$ can be made as follows:

- if $0.00 \leq \alpha \leq 0.40$, the meter is unreliable;

- if $0.40 \leq \alpha \leq 0$. 0 , the reliability of the meter is low;

- if $0.0 \leq \alpha \leq 0.80$, the meter is very reliable; and

- if $0.80 \leq \alpha \leq 1.00$, the meter is a high reliability meter.

Alpha is the model with respect to the correlation between variables. This coefficient takes two values: $\mathrm{o}$ and 1.

Reliability Statistics

\begin{tabular}{|c|c|c|}
\hline Cronbach's Alpha & Cronbach's Alpha Based on Standardized Items & N of Items \\
\hline .712 & .976 & 6 \\
\hline
\end{tabular}

In our case, the alpha coefficient is 71.2, which indicates that the meter is very reliable as it is within the range of o - 8o (i.e. 71.2\%). This indicates that all variables must participate in the model. Based on the fact that the significance of the variables in all cases is 0.000 , then the null hypothesis is rejected, and the alternative hypothesis is accepted. The data is not random.

To analyse the relationship between public debt and economic growth, an econometric analysis was conducted through the SPSS program. GDP is taken as a dependent variable, and public debt amounts, remittances, export earnings, average pay increases over years, and the amount of government subsidies are taken as independent variables. These data were taken from reports published by the Ministry of Finance; Kosovo Agency of Statistics; Kosovo Custom's official website; and the World Bank. Data were obtained from 2009 to 2016 on a monthly basis.

The analysis shows that:

Tab. 1.1: Descriptive Statistics

Descriptive Statistics

\begin{tabular}{|l|c|c|c|}
\hline & Mean & Std. Deviation & N \\
\hline GDP & 410.5192 & 58.71254 & 96 \\
Public debt & 39.9463 & 18.16603 & 96 \\
Remittances & 50.6900 & 5.70911 & 96 \\
Wage & 29.9450 & 5.60766 & 96 \\
Export & 27.8300 & 5.11442 & 96 \\
Subsidies & 27.3525 & 7.15915 & 96 \\
\hline
\end{tabular}

Mean and standard deviation of dependent variables and independent variables. The standard deviation is the measure of variation or dissemination of data, or the probability distribution. Low standard deviation means that data points are grouped very close to the same value (mean), while high standard deviation implies that the data are located in a larger set of values.

Tab.1.2: Correlation between Variables

Correlations

\begin{tabular}{|ll|c|c|c|c|c|c|}
\hline & & GDP & Public debt & Remittances & Wage & Export & Subsidies \\
\hline \multirow{4}{*}{ Pearson Correlation } & GDP & 1.000 & .963 & .950 & .986 & .794 & .948 \\
& Public debt & .963 & 1.000 & .869 & .921 & .673 & .990 \\
& Remittances & .950 & .869 & 1.000 & .950 & .795 & .845 \\
& Wage & .986 & .921 & .950 & 1.000 & .801 & .896 \\
& Export & .794 & .673 & .795 & .801 & 1.000 & .698 \\
& Subsidies & .948 & .990 & .845 & .896 & .698 & 1.000 \\
\hline
\end{tabular}




\begin{tabular}{|c|c|c|c|c|c|c|c|}
\hline \multicolumn{8}{|c|}{ Correlations } \\
\hline & & GDP & Public debt & Remittances & Wage & Export & Subsidies \\
\hline \multirow{6}{*}{ Sig. (1-tailed) } & GDP & & .000 & .000 & .000 & .000 & .000 \\
\hline & Public debt & .000 & . & .000 & .000 & .000 & .000 \\
\hline & Remittances & .000 & .000 & . & .000 & .000 & .000 \\
\hline & Wage & .000 & .000 & .000 & & .000 & .000 \\
\hline & Export & .000 & .000 & .000 & .000 & • & .000 \\
\hline & Subsidies & .000 & .000 & .000 & .000 & .000 & . \\
\hline \multirow{6}{*}{$\mathrm{N}$} & GDP & 96 & 96 & 96 & 96 & 96 & 96 \\
\hline & Public debt & 96 & 96 & 96 & 96 & 96 & 96 \\
\hline & Remittances & 96 & 96 & 96 & 96 & 96 & 96 \\
\hline & Wage & 96 & 96 & 96 & 96 & 96 & 96 \\
\hline & Export & 96 & 96 & 96 & 96 & 96 & 96 \\
\hline & Subsidies & 96 & 96 & 96 & 96 & 96 & 96 \\
\hline
\end{tabular}

From the chart obtained we see that the relation between public debt and economic growth, according to the results of the analysis, turned out to be quite strong. The correlation value showing the relevance in the two variables (the dependent and the unrelated) in this case is $96.3 \%$ - a very strong positive connection.

The relevance of the other independent variables is also quite strong, with the dependent variable being GDP. The correlation between remittances and GDP is $95.0 \%$, with the average pay increase rising to $98.6 \%$. An increase in wages will result in an increase in demand for goods and services. Therefore, people are ready to consume more. Demand for higher consumption will increase GDP, and this will increase the growth rate. The relationship between GDP and export is $79.4 \%$. The correlation between GDP and subsidies is positive and quite strong, with a $94.8 \%$ share.

The significance of the hypothesis or the significance of the model as a whole in this case is o.ooo, which substantiates the hypothesis, the alternative hypothesis is accepted, and the basic hypothesis is rejected. There is always a probabilistic component involved in accepting or rejecting the decision during hypothesis testing. Therefore, the criterion used for accepting or rejecting a null hypothesis is called the significance level, or value - Q. So in this case, the significance is $0.000<0.05$ and indicates that all hypotheses of the model are accepted. Therefore, the results show that the significance of all variables is 0.000 , and the model has statistical significance.

Fig. 1.3: Regression

\section{Model Summary}

\begin{tabular}{|c|c|c|c|c|c|}
\hline & & & & & Change Statistics \\
\hline |Model & $\mathrm{R}$ & R square & Adjusted R Square & Std. Error of the Es & 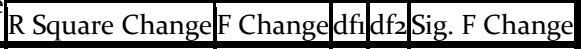 \\
\hline 1 & .998 & 997 & .997 & 3.41298 & \begin{tabular}{|l|l|l|}
5604.740 & 5 & 90 \\
\end{tabular} \\
\hline
\end{tabular}

a. Predictors: (Constant), Subsidies, Export, Remittances, Wage, Public debt

Linear regression shows how many independent variables explain the dependent variable, which in this case is $99.7 \%$. Thus if public debt is used prudently, then there will be economic growth in the country. Like all other independent variables explain the dependent variable in this case is GDP. The correlation value of all independent variables with the dependent variable is $99.8 \%$, which is a fairly strong correlation. The overall significance of the model is o.ooo, indicating that the model is within the $95 \%$ confidence interval. 
Fig. 1.4: Results Obtained from Alpha and Beta Analysis.

Coefficients

\begin{tabular}{|c|c|c|c|c|c|c|c|}
\hline \multirow{2}{*}{ Model } & \multicolumn{2}{|c|}{ Unstandardized Coefficients } & \multirow{2}{*}{\begin{tabular}{|c|} 
Standardized Coefficients \\
Beta \\
\end{tabular}} & \multirow{2}{*}{$\mathrm{t}$} & \multirow{2}{*}{ Sig. } & \multicolumn{2}{|c|}{$95.0 \%$ Confidence Interval for B } \\
\hline & $\mathrm{B}$ & Std. Error & & & & Lower Bound & Upper Bound \\
\hline (Constant) & 114.465 & 9.185 & & 12.462 . & .000 & 96.217 & 132.713 \\
\hline Public debt & .852 & .226 & .264 & 3.764 & .000 & .402 & 1.302 \\
\hline Remittances & 1.466 & .202 & .143 & 7.255 & .000 & 1.065 & 1.868 \\
\hline Wage & 4.863 & .310 & .465 & 15.689. & .000 & 4.248 & 5.479 \\
\hline Export & .588 & .162 & .051 & 3.625 & .000 & .266 & .910 \\
\hline Subsidies & .938 & .487 & .114 & 1.927 & .057 & -.029 & 1.906 \\
\hline
\end{tabular}

a. Dependent Variable: GDP

When the public debt and all other independent factors are equal to o, then GDP will be 114.465, and when the public debt increases for the same time, we understand that when the public debt is increased by 1 times and used cautiously then GDP will increase by 0.852 , when all other factors remain constant. Therefore, careful use of the public debt, such as investment, job creation, and productivity growth, can all affect the country's economic growth and financial stability. Otherwise, misuse of public debt will inadvertently affect the country's destabilization, create an inflationary situation, and will only continue to increase liabilities to lenders, having no positive impact on the country. Reckless use of the public debt will have a direct effect on lowering the economic growth rate.

Another factor that can increase GDP is remittances: when they increase by 1, then GDP will increase by 1.466 , with all other factors remaining constant. If individuals have more income, they will consume more normal goods than inferior goods, and this will increase consumption, while consumption as a major component of GDP will increase it.

The Central Bank of Kosovo states that remittance inflows in Kosovo constitute one of the most important sources of foreign financing, thus dominating discussions on sources of economic growth, alleviating the trade deficit gap, reducing poverty in the country, or attracting foreign investment. When the average wage rises by 1 , then GDP will rise by 4.863 , when other factors remain unchanged. An increase in wages will result in an increase in demand for goods and services. Thus people are ready to consume more. Demand for higher consumption will increase GDP, and this will increase the growth rate. Export is also one of the key factors of economic growth: when export within the country increases by 1 , then GDP increases by 0.588 , while other factors remain constant. Exports can increase intra-industry trade and help the country integrate into international markets, thus reducing the impact of external shocks on the country's economy. Economics experts believe that the role of exports is essential for the development of a state.

The significance of all model factors is less than $0.05 \%$, or in the case of subsidies, equal to 0.05 , indicating that the model is within the $95 \%$ confidence interval.

Fig. 1.5: ANOVA

ANOVA $^{\mathrm{a}}$

\begin{tabular}{|l|c|c|c|c|c|}
\hline Model & Sum of Squares & df & Mean Square & F & Sig. \\
\hline Regression & 3796491.361 & 2 & 1898245.681 & 65.487 & .ooo $^{\text {b }}$ \\
1 Residual & 144932.639 & 5 & $\mathbf{2 8 9 8 6 . 5 2 8}$ & & \\
Total & 3941424.000 & 7 & & & \\
\hline
\end{tabular}

a. Dependent Variable: Y.GDP nominal

b. Predictors: (Constant), $\mathrm{X}_{4}$ taxes, $\mathrm{X} 8$ Investment in education

To make the model as reliable and important as possible, it is also validated by an f-test. The F-test represents a general model test which shows whether there is a significant correlation between the unadjusted and the dependent variables. 


\section{$65.487>11.070$}

This test also confirms that the hypotheses in the paper are accepted and that the model is statistically significant.

\subsection{Factor analysis}

Factorial analysis is one of the multivariate statistical techniques widely used to reduce the number of variables that are related to each other to a small number of significant and independent factors. Three methods were used to evaluate the suitability of the dataset for the factorial analysis: the creation of the correlation matrix, Bartlett's test, and the Kaiser-Meyer-Olkin (KMO) test. As a rule, the KMO test should be greater than 0.50 in order to say that the dataset is suitable for factorial analysis. In our case KMO analysis is 0.781 or $78.1 \%$, which means that it is higher than 0.50 and that we can say that the variables are suitable for factorial analysis.

KMO and Bartlett's Test

\begin{tabular}{|c|c|c|}
\hline \multicolumn{3}{|c|}{ Kaiser-Meyer-Olkin Measure of Sampling Adequacy } \\
\hline & Approx. Chi-Square & 1446.044 \\
\hline \multirow[t]{2}{*}{ Bartlett's Test of Sphericity } & df & 15 \\
\hline & Sig. & .000 \\
\hline
\end{tabular}

The second test we will look at is Bartlett's test. As can be seen from the table, Bartlett's test is significant at a significance of o.ooo. This means that there are high positive correlations between variables; in other words, this analysis shows that our dataset is suitable for factorial analysis. All of these factors together explain $89.59 \%$ of the variance of the model.

Total Variance Explained

\begin{tabular}{|c|c|c|c|c|c|c|}
\hline \multirow{2}{*}{ Component } & \multicolumn{4}{|c|}{ Initial Eigenvalues } & \multicolumn{3}{c|}{ Extraction Sums of Squared Loadings } \\
\cline { 2 - 7 } & Total & \% of Variance & Cumulative \% & Total & \% of Variance & Cumulative \% \\
\hline 1 & 5.376 & 89.594 & 89.594 & 5.376 & 89.594 & 89.594 \\
2 & .416 & 6.930 & 96.524 & & & \\
3 & .158 & 2.633 & 99.156 & & & \\
4 & .044 & .735 & 99.892 & & & \\
5 & .004 & .068 & 99.960 & & & \\
6 & .002 & .040 & 100.000 & & & \\
\hline
\end{tabular}

Extraction Method: Principal Component Analysis.

The Scree test graph (line graph) shows the total variance with respect to each factor. Factors found on the point of horizontal axis are accepted as the maximum factors to be obtained.

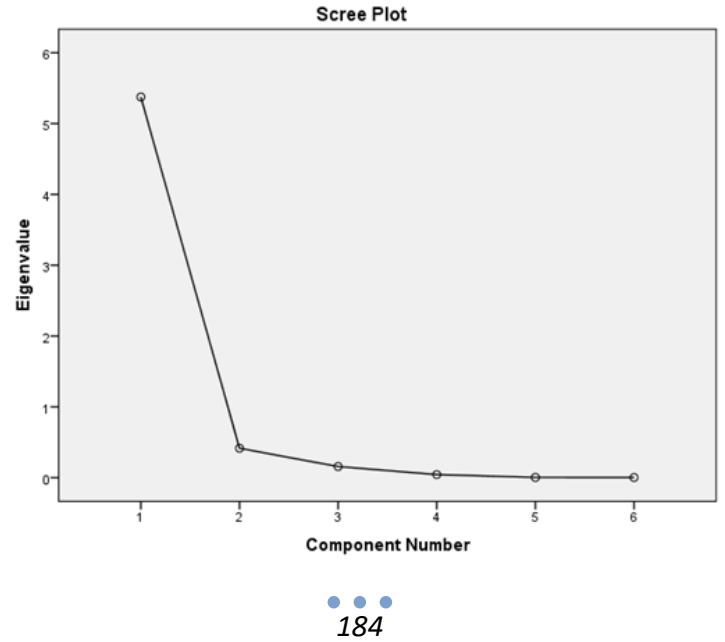




\section{Conclusion}

The purpose of this paper was to present the precise relationship between public debt and GDP in the Republic of Kosovo from 2009 to 2016. According to many previous studies, it was clear that many well-known economists think that the public debt has a positive impact on the economy, and others have thought the public debt was devastating for a country's economy. Public debt has its advantages when used for the right destination, but it can have devastating effects on a country's economy when debt is used in the wrong projects. How effective is public debt spending? And, if Kosovo's public debt is used for important projects that affect job creation and economic growth, then it is customary not to be overly concerned.

The results of the empirical analysis lead to the conclusion that export to Kosovo has a positive effect on economic growth. Exports of goods and services represent a very important source of foreign exchange earnings, and consequently reduce the pressure on the balance of payments. There are various factors that contribute to economic growth, but exports are considered one of the most important contributors. Our empirical analysis proved that exports have a very positive impact on economic growth.

An increase in wages will result in an increase in demand for goods and services, as people will be ready to consume more. Demand for higher consumption will increase GDP, and this will increase the growth rate. The Central Bank of Kosovo states that remittance inflows in Kosovo constitute one of the most important sources of foreign financing, thus dominating discussions on sources of economic growth, alleviating the trade deficit gap, and reducing poverty in the country. Our econometric analysis proved this, resulting in a correlation between the two variables, or a $95.0 \%$ correlation value.

\section{Recommendations}

- When public debt becomes a global phenomenon, government policies can only be effective if they are oriented towards the sustainability and affordability of public debt.

- The government should pay close attention to money management, which should be carefully planned and monitored so as not to impose an increase in public debt that may be difficult to settle for high-cost liabilities.

- Current capacities for job creation and economic development must be measured, and budget capacities should be carefully measured for those capacities, rather than embedded in uncontrolled debts that would burden future generations.

- To avoid the potential risk of increasing the level of BP in Kosovo, a national strategy should be developed. The strategy must be in line with our development capacity, and public debt in particular should be allocated to building new energy capacities.

- Public debt should be maximally utilized in investment policies in order to generate output, reduce unemployment, and increase exports, among other approaches, so if external debt is not used to generate income in a given period of time, then it will have a tremendous negative impact on GDP and the country economy in its entirety. Improving the position of Kosovo's exports in competition will also require infrastructure investments, legislative improvements, and institutional capacity-building including:

- Investing in transport infrastructure to cope with rising demand; and

- Increasing the efficiency of institutional infrastructure dealing with trade.

\section{References}

Barro Robert J. (1979). On the determination of the Public Debt. Journal of Political Economy 87 (5), 940.

Burnside, C. and D. Dollar. (20oo). Aid, Policies, and Growth. American Economic Review , 847. 
Carmen M. Reinhart \& Kenneth S. Rogoff. (2010). Growth in a Time of Debt. American Economic Association, vol. $100(2), 573$.

Cecchetti, S.G., \& Mohanty, M.S., \& Zampolli, F. (2011). The real effects of debt, Bank for International. BIS, 21.

Chowdhury, A. R. ((2001)). External Debt and Growth in Developing Countries; A Sensitivity and Causal Analysis. WIDER Discussion Paper No. 2001/95, 45-65.

J, Alves. (2008). The role of Government debt on Economic Growth.

Kadriu, S. ( 2016). Financa Publike. Prishtinë: Prishtinë.

Kryeziu, R. (2014). Financat Publike. Prishtinë.

Kumar, M.S., Woo, J. (2010). "Public debt and growth. International Monetary Fund Working".

Miszatel, P. (2010). Public debt and economic growth in the European Union. Poland: Journal of Applied Economic Sciences.

Nexhmije Berisha Vokshi. (2013). Kontabiliteti i sektorit publik. Prishtinë.

Pano, A. (2002). Fjalor Ekonomiko-Financiar. Tiranë.

Ugo Panizza \& Andrea F. Presbitero (2013). Public debt and economies in growth in advanced economies: A survey. Swiss Society of Economics and Statistics. Vol. 149 (2) 175-204

Wenzel, Heinz-Dieter; Lackenbauer, Jörg; Brösamle, Klaus J. . (n.d.). Borxhi publik dhe Pakti i Stabilitetit. 